\title{
Species diversity, population structure, and regeneration status of trees in Fakim Wildlife Sanctuary, Nagaland, Northeast India
}

\author{
AOSANEN AO ${ }^{1}$, SAPU CHANGKIJA ${ }^{2}$, SHRI KANT TRIPATHI ${ }^{1, v}$ \\ ${ }^{1}$ Department of Forestry, Mizoram University. Aizawl-796004, Mizoram, India. Tel.: +91-8794154869, `email: sk_tripathi@ rediffmail.com \\ ${ }^{2}$ Department of Genetics and Plant Breeding, Nagaland University. Medziphema-797106, Nagaland, India
}

Manuscript received: 12 April 2020. Revision accepted: 26 May 2020.

\begin{abstract}
Ao A, Changkija S, Tripathi SK. 2020. Species diversity, population structure, and regeneration status of trees in Fakim Wildlife Sanctuary, Nagaland, Northeast India. Biodiversitas 21: 2777-2785. The plant species composition and diversity represent the overall health of the forest ecosystems and provide useful insight on forest conservation, and the species regeneration is important in assessing the potential of the forests to serve the society on sustained basis. This present study aimed to assess the species diversity, population structure, and regeneration status of the trees in temperate forest of Fakim Wildlife Sanctuary, Nagaland, Northeast India. Tree species composition, population structure and regeneration status were analyzed by randomly establishing eight plots of 0.1 ha within the sanctuary. Density, basal area, abundance, evenness, and other diversity indices were calculated for mature trees with girth at breast height $(\mathrm{GBH}) \geq 30 \mathrm{~cm}$. A total of 60 tree species belonging to 40 genera and 27 families were recorded. The most dominant families recorded were Lauraceae and Rosaceae. The total tree density recorded from the forest was 432.5 individuals ha ${ }^{-1}$ with a basal area $42.8 \mathrm{~m}^{2} \mathrm{ha}^{-1}$. Cinnamomum zeylanicum and Lithocarpus pachyphyllus had the highest density with 17.58 individuals ha-1 and Lithocarpus pachyphyllus had the highest basal area with $2.64 \mathrm{~m}^{2} \mathrm{ha}^{-1}$. The species with the highest IVI was Betula alnoides (17.13). Girth class of 30-60 cm had the highest density and basal area with 280 individuals ha-1 and $20.7 \mathrm{~m}^{2} \mathrm{ha}^{-1}$. The diversity indices such as Shannon-Wiener index, Simpson index, Pielou evenness index, and Margalef species richness index were 3.90, 0.93, 0.92, and 11.59, respectively in the wildlife sanctuary. The present study showed that $41 \%$ of tree species exhibited good regeneration status, $31 \%$ as fair regeneration, $8 \%$ as poor regeneration and $20 \%$ had no regeneration. The present data will be useful to understand the current status of tree species and will serve as baseline information to the forest department, policymakers and conservationists to develop management plans for the conservation of priority species in the area.
\end{abstract}

Keywords: Fakim Wildlife Sanctuary, temperate forest, population structure, regeneration potential, tree diversity

\section{INTRODUCTION}

Forest is an association of plant community dominated by trees of different sizes and other woody and non-woody vegetations like shrubs and herbs occupies various storeys (Zhang et al. 2017). Plant composition in a forest ecosystem is largely influenced by geographical location of the region, soil, climate, stand structure, tree diversity, and regeneration pattern of species (Sarkar and Devi 2014, Siregar et al. 2019). Species diversity is an important component of the forest ecosystems as it reflects the overall health of forest, and provides useful information that serves as primary information for the conservation of tree species and habitats including other organisms of the forest ecosystems (Roy et al. 2004, Sharma and Kant 2014). Vegetation analysis of the forest ecosystem will help us to understand the population structure (Sahu et al. 2019) and regeneration potential of the species which can be useful in forest management and species conservation (Borogayary et al. 2017) and their economic valuation (Palit et al. 2012).

Regeneration is the most integral part of any forest ecosystem as it determines the existence of species in the region (Malik and Bhatt 2016) and it plays a major role in forest management (Ahmadi et al. 2016, Saroinsong 2020). Successful regeneration of species is one of the main driving forces to achieve future sustainability of the forest community (Saikia and Khan 2013). Regeneration status of a forest is determined by the density of seedling, sapling, and population of species in lower girth classes (Deb and Sundriyal 2011; Maua et al. 2020). The higher density of seedlings and saplings, and the presence of young trees in lower girth class indicate a good regeneration status of forest whereas the absence of seedling results in no regeneration (Senbeta et al. 2014; Pokhriyal et al. 2010; Chaturvedi et al 2017; Sharma et al. 2018). The population structure of individual species present in different girth classes (e.g. $30-60 \mathrm{~cm}, 60-90 \mathrm{~cm}, 90-120 \mathrm{~cm}$, etc.) in association with regeneration behavior of the forest helps us to provide better understanding on the potential of the forest (Dutta and Devi 2013) to serve the society and the anthropogenic pressure faced by the forest. For instance, the population structure characterized by least number of seedling and saplings as compared to mature trees suggests a poor regeneration status, whereas, absence of seedlings depicts no regeneration in the forest (Rahman et al. 2011). Therefore, forest stand structure and regeneration status of the species is a key element to determine the health of forest ecosystem and also important parameters of stand biodiversity (Rahman et al. 2019).

According to World Conservation Monitoring Centre, India is one of the 17 mega biodiversity countries in the world and the country has four biodiversity hotspots 
consisting of Western Himalaya, Eastern Himalaya, IndoBurma, and Western Ghats (Arisdason and Lakshminarasimhan 2017). Northeast India is comprised of eight states, namely Arunachal Pradesh, Nagaland, Manipur, Meghalaya, Assam, Tripura, Mizoram, and Sikkim, which harbors $75 \%$ of the floral and faunal diversity of the country. Northeast India covering an area of $262179 \mathrm{~km}^{2}$ (Upadhaya et al. 2012) is a part of IndoBurma biodiversity hotspots. The region is rich in biodiversity with majority of endemic species are facing high degree of threats. Further, the region is characterized by high variation in altitudes, soil types, and ecological conditions along with diverse life forms which provide necessary conditions for the region to serve as storehouse of varieties of plant and animal species (Tynsong and Tiwari 2010; Saikia and Khan 2017). According to World Wildlife Foundation, the entire Eastern Himalayas, which consists of entire eight states of Northeast India and the neighboring countries like Bhutan, Southern China, and Myanmar, have been listed among 200 Global Ecoregion (Saikia et al. 2017, Roy et al. 2015). One protected area within this region is Fakim Wildlife Sanctuary.

Fakim Wildlife Sanctuary has been named after Fakim village, which is located at the foothills of Mount Saramati in the Eastern part of Kiphire District, Nagaland, and shares international boundary with Myanmar. The sanctuary is very rich in flora and fauna with many rare, endangered, and endemic species but most of the area in the sanctuary is unexplored due to its high altitude and slopes. Therefore, it is important to conduct detailed documentation and analysis of vegetation of the sanctuary which will serve as baseline information to the forest department, researchers, ecologist, and conservationist. The main aim of this study is to assess species diversity, composition, population structure and regeneration potentials of the tree in wet temperate forest of Fakim Wildlife Sanctuary, Nagaland, Northeast India.

\section{MATERIALS AND METHODS}

\section{Study area}

The Fakim Wildlife Sanctuary lies between N $25^{\circ} 47^{\prime}$ $25^{\circ} 48^{\prime}$ and $\mathrm{E} 95^{\circ} 02^{\prime}$ to $95^{\circ} 04^{\prime}$ (Figure 1) at altitudes of 1700-3000 m above sea level with an area of $6.42 \mathrm{~km}^{2}$. It was declared sanctuary in the year 1986. The sanctuary is composed of thick virgin primary forest of wet temperate to sub-alpine forest types (Champion and Seth 1968). The area is part of the Indo-Burma border which is considered as one of world's biodiversity hotspots (Rongsensashi et al. 2013). The Fakim Wildlife Sanctuary is known for the habitat of rare and endangered bird species Blyth tragopan (Tragopan blythii), which is also known to be the state bird of Nagaland. The forest receives an annual rainfall of 200$300 \mathrm{~cm}$ with temperature varying from $5^{\circ} \mathrm{C}$ in winter to $29^{\circ} \mathrm{C}$ in summer. The whole region lies in the biogeographic zone of Northeast India and also acts as a transition zone between India, Indo-Burma, and Indo-China biogeographic zones (Chatterjee et al. 2006). The sanctuary harbors many important faunal species, such as Chinese goral, leaf deer, bay woodpecker, wedge-tailed greenpigeon, Blyth tragopan, wild dog, sun bear, hoolock gibbon, Himalayan black bear, etc. There were few sightings of top predators, like tigers, in the region between Mt. Saramati and Fakim Wildlife Sanctuary, but occasionally only bug marks were spotted and there is no proper documentation of tigers from the sanctuary. Due to very rough terrain, less road accessibility, and unaccountable challenges, the floral community of the sanctuary has not been explored despite the rich biodiversity of the region.

\section{Data collection}

The present study was conducted during the month of May-July, 2017 in wet temperate forest of Fakim Wildlife Sanctuary, Nagaland. Random quadrats measuring $20 \mathrm{~m} \mathrm{x}$ $25 \mathrm{~m}$ were used to study the vegetation of the area. A total of 8 quadrats of 0.1 ha each was established randomly with help of metal tapes using the ropes for making the grids and all individuals of tree species were identified, recorded, and collected. Measuring tape was used to measure the girth of trees $(1.37 \mathrm{~m}$ girth at breast height) and identification of species was made by experts in the field and herbarium was prepared and deposited in herbarium laboratory, Nagaland University, Medziphema.

All the individuals $\geq 30 \mathrm{~cm}$ girth $(\mathrm{GBH})$ were considered as adult trees, individuals $\geq 10-\leq 30 \mathrm{~cm}$ girth were considered as old sapling/young trees/shrubs as the case may be depending on nature, individuals with $>10 \mathrm{~cm}$ height and 3 to $<10 \mathrm{~cm}$ girth $(\mathrm{GBH})$ were considered as saplings and individuals with up to $10 \mathrm{~cm}$ tall and $<3 \mathrm{~cm}$ girth $(\mathrm{GBH})$ were considered as seedlings.

\section{Data analysis}

Community parameters such as frequency, density, basal area, and dominance were quantitatively analyzed (Singh et al. 2015). The Important Value Index (IVI) of each tree species was also calculated. The number of individuals of all adult trees was recorded in different girth classes, such as $30-60 \mathrm{~cm}, 60-90 \mathrm{~cm}, 90-120 \mathrm{~cm}, 120-150$ $\mathrm{cm}, 150-180 \mathrm{~cm}$, and $\geq 180 \mathrm{~cm}$ to understand the population structure of species in the area. Regeneration status of each individual species was studied based on the size of population of seedling, sapling, and adult trees (Shankar 2001). Regeneration was considered as "good" if seedlings > saplings > trees; "fair" if seedlings > or < saplings < trees; "poor" if there is no seedling but species survives in sapling stage and "no regeneration" if species survives only in adult tree stage (Khumbongmayum et al. 2006).

Important diversity indices were also computed to study the species richness, diversity, dominance, and evenness of the plant community. 1963)

Shannon-Weiner diversity index (Shannon and Weiner

\section{$\mathrm{H}^{\prime}=-\sum_{\mathrm{i}=1}^{\mathrm{s}}(p i) \ln (p i) ;(\ln$ is a natural $\log )$}

Where, $P_{i}$ is the proportion $(n / N)$ of individuals of one particular species (n) divided by total number of individuals found $(\mathrm{N})$ 


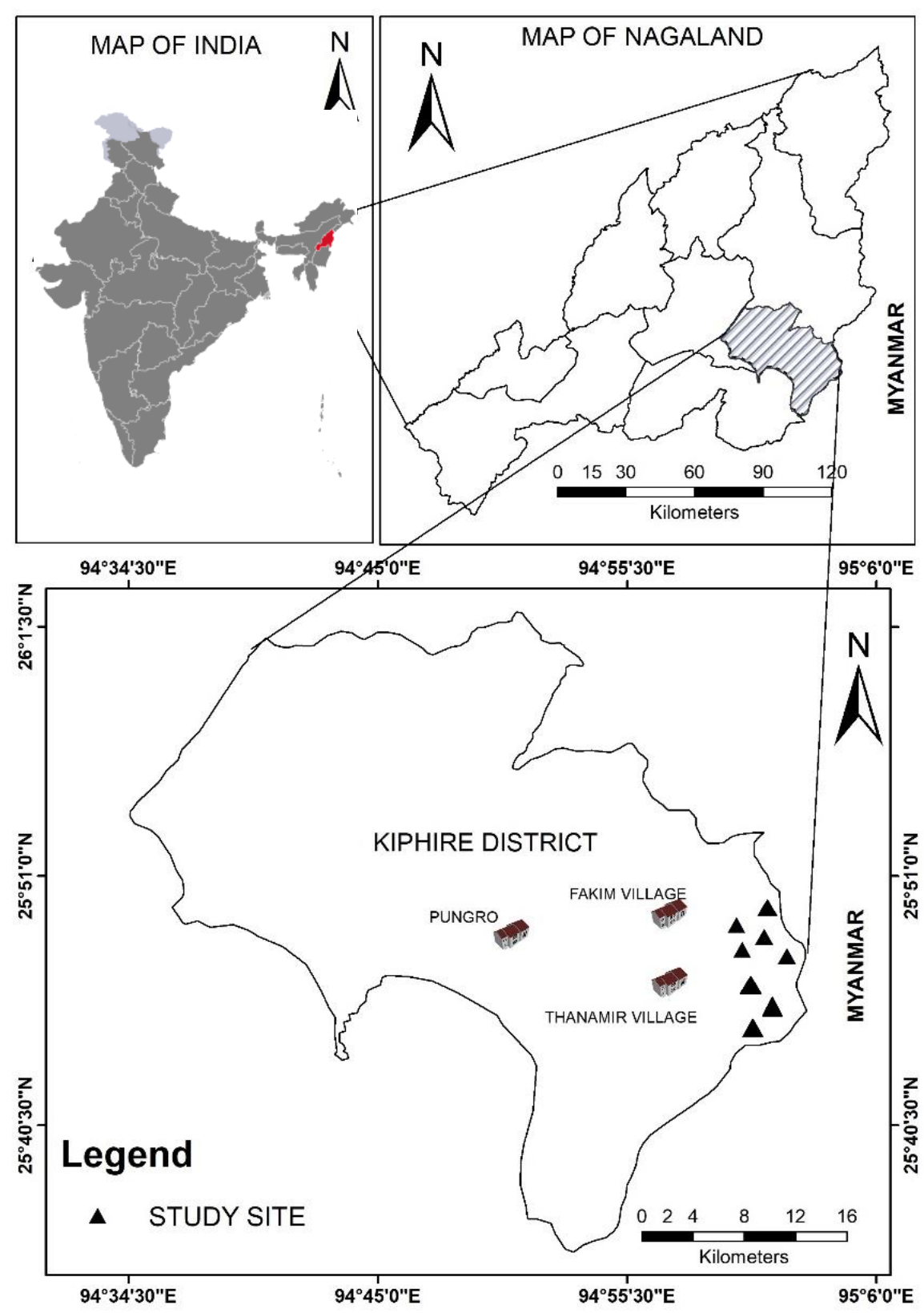

Figure 1. Map showing the study site and surrounding villages of Fakim Wildlife Sanctuary, Kiphire District, Nagaland, Northeast India

Simpson dominance index (Simpson 1949)

$\mathrm{Cd}=\sum_{\mathrm{i}=1}^{\mathrm{s}}(p i)^{2}$

Margalef species richness index (Margalef 1958)

$\mathrm{d}=\mathrm{S}-1 / \ln (\mathrm{N})$

Where, $\mathrm{S}$ is the total number of species and $\mathrm{N}$ is the total number of individuals

Pielou evenness index (Pielou 1966)

$$
\mathrm{E}=\mathrm{H}^{\prime} / \operatorname{Ln}(\mathrm{S})
$$

Where $\mathrm{H}^{\prime}$ is the Shannon-Weiner diversity index and $\mathrm{S}$ is the total number of species

\section{RESULTS AND DISCUSSION}

\section{Floristic diversity and composition}

A total of 60 tree species belonging to 40 genera and 27 families was recorded from the temperate forest of Fakim Wildlife Sanctuary, Kiphire Nagaland (Table 1). The most dominant families recorded were Lauraceae and Rosaceae (6 species each), followed by Sapindaceae, Fagaceae, and Magnoliaceae (4 species each), and Elaeocarpaceae, Fabaceae, Meliaceae, Moraceae and Theaceae (3 species each). The number of tree species recorded in this study was comparable to Montane wet temperate forest of the Southern Western Ghats, India (Somasundaram and Lalitha 2010, 67 species) and Temperate forest of Talle wildlife sanctuary, Arunachal Pradesh, Eastern Himalaya (Yam and Tripathi 2016, 63 species); whereas, the values were lower 
compared to 13 montane forests of Bawean Island Nature Reserves, Indonesia (Trimanto and Hapsari 2016, 237 species), plant species diversity along with altitude range in West Himalaya, Uttarakhand, India (Rawal et al. 2018, 106 species), forest composition along altitudinal gradient in Eastern Himalaya, Sikkim, India (Bhutia et al. 2019, 114 species) and tropical dry deciduous forest of Eastern Ghats, India (Gandhi and Sundarapandian 2020, 75 species). However, the tree species richness of the present study was found to be higher as compared to plant diversity recorded in a southern temperate forest in Tierra del Fuego Island, Argentina (Mestre et al. 2017, 46 species); a wet temperate forest in Pakistan (Raja et al. 2014, 44 species) and in a temperate forest in Bertiz Natural Park, Spain (Gazol and Ibanez 2010, 28 species).

Betula alnoides showed the highest importance value index (IVI) with 17.13 followed by Lithocarpus pachyphyllus (12.50), Quercus lamellosa (10.58) and Lithocarpus xylocarpus (9.00) (Table 2). The total tree density recorded from the forest was 432.5 individuals ha- ${ }^{-1}$. Cinnamomum zeylanicum and Lithocarpus pachyphyllus contributed the highest density with 17.58 individuals ha ${ }^{-1}$, followed by Acer oblongum and Magnolia insignis with 16.04 individuals $\mathrm{ha}^{-1}$ and Betula alnoides and Michelia oblonga with 15.03 individuals $\mathrm{ha}^{-1}$ each. The tree density of present study was lower than that of a temperate forest in West Himalaya, India (Airi and Rawal 2017, 393-789 individuals $\mathrm{ha}^{-1}$ ), and a temperate forest of Quercus leucotrichophora in Dewalgarh watershed, Garhwal Himalaya (Uniyal et al. 2010, 804-2144 individuals ha ${ }^{-1}$ ). However, it was comparable to density recorded in a temperate forest in Dhanaulti, Garhwal Himalaya (Saha et al. 2016, 83.33-211.67 individuals ha ${ }^{-1}$ ).

The total basal area recorded from the present study was $42.8 \mathrm{~m}^{2} \mathrm{ha}^{-1}$. Lithocarpus pachyphyllus contributed the highest basal area with $2.64 \mathrm{~m}^{2} \mathrm{ha}^{-1}$, followed by Michelia oblonga $\left(2.03 \mathrm{~m}^{2} \mathrm{ha}^{-1}\right)$, Exbucklandia populnea $\left(1.80 \mathrm{~m}^{2}\right.$ ha $\left.{ }^{1}\right)$ and Cinnamomum zeylanicum $\left(1.53 \mathrm{~m}^{2} \mathrm{ha}^{-1}\right)$. Similar study was conducted by various workers where the basal area of tree species ranged from 24.2-75.3 $\mathrm{m}^{2} \mathrm{ha}^{-1}$ (Tropical forest of Western Ghats, India; Subashree et al. 2020); 22.21-46.73 $\mathrm{m}^{2} \mathrm{ha}^{-1}$ (Tropical moist deciduous forest of Saptasajya Hill range, Eastern Ghats, India; Sahu et al. 2019) and $94.18 \mathrm{~m}^{2} \mathrm{ha}^{-1}$ (Tropical forest of Baratang Island, India; Mane et al. 2019).

The species diversity indices are very essential to determine the health status of a forest ecosystem. In this study, various diversity indices were also enumerated to understand the richness of the forest (Table 1). According to Sobuj and Rahman (2011), an ecosystem with rich species diversity has higher value of $\mathrm{H}^{\prime}$ index whereas an ecosystem with lower species diversity has of lower value of such index. In the present study, tree species diversity $\left(\mathrm{H}^{\prime}\right)$ in Fakim Wildlife Sanctuary was 3.90, which can be considered as high for temperate and tropical forests. For example, species diversity reported from mixed forest of Batuputih Nature Tourism Park, Indonesia was 3.31 (Arrijani and Rizki 2020), Takamanda rainforest in Southwest Cameroon was 3.87 (Ndah et al. 2013) and temperate forest of Rudraprayag district of Garhwal
Himalaya was 3.45 (Raturi 2012). The variation in species diversity with respect to environmental gradient acts as a major ecological investigation (Deb et al. 2015; Erenso et al. 2014; Gairola et al. 2008), and various factors, such as climate, habitat, biotic interaction, edaphic, physiography, and productivity of the forest, play a major role in determining the species growth and production (Monson 2014; Sharma et al. 2014).

The dominance value (Ds) recorded in present study (0.93) corresponds well with that recorded from other temperate forests, which ranged from 0.135-0.97 (Saha et al. 2016; Ndah et al. 2013). The Pielou evenness index (e) recorded from the present study (0.92) revealed that there is an even distribution of species within the forest. Higher value of evenness indicates more consistency in species distribution (Sarkar and Devi 2014). Margalef richness index (d) to determine the species richness of the study site showed a value of 11.45 , which was similar to those reported from Meghalaya (Lynser and Tiwari 2015), Eastern Ghats (Naidu and Kumar 2016), and Western Ghats (Sathish et al. 2013) (Table 1).

\section{Population structure}

The highest number of tree species was recorded at the adult stage (60 species), followed by young sapling (34 species), old sapling (18), and seedling (29 species). The maximum density was recorded at the seedling stage (3100 individuals $\left.\mathrm{ha}^{-1}\right)$, followed by the young sapling (2800 individuals $\left.\mathrm{ha}^{-1}\right)$, old saplings/young trees (1550 individuals $\mathrm{ha}^{-1}$ ) and trees (432.5 individuals ha' ${ }^{-1}$ ) (Figure 2). Among the seedling, Berberis aristata, Lithocarpus pachyphyllus, Acer pectinatum, Elaeocarpus lanceifolius, Litsea monopetala, and Toona sureni contributed about one-third of the total seedling density. Further, among the sapling species, Albizia odoratissima, Cephalotaxus griffithi, Elaeocarpus lanceifolius, Michelia spp., Rhododendron arboretum, Schima khasiana, Shorea assamica contributed about one-third of the total sapling density. The old saplings of dominant species like Acer laevigatum, Acer thomsonii, Betula alnoides, Cephalotaxus grifithii and Prunus cerasoides indicate an established species population with a good regeneration potential of the forest. Similar species structure has been reported in temperate forests of Western Himalaya (Tripathi et al. 1987).

Table 1. Phytosociological attributes of tree community in Fakim Wildlife Sanctuary, Nagaland, Northeast India

\begin{tabular}{ll}
\hline Parameters & Value \\
\hline Number of species & 60 \\
Number of genera & 40 \\
Number of families & 27 \\
Stand density $\left(\right.$ Individuals $\left.\mathrm{ha}^{-1}\right)$ & 432.5 \\
Basal area $\left(\mathrm{m}^{2} \mathrm{ha}^{-1}\right)$ & 42.8 \\
Shannon-Wiener index $\left(\mathrm{H}^{\prime}\right)$ & 3.9 \\
Simpson index (Ds) & 0.93 \\
Margalef index (d) & 11.45 \\
Pielou evenness (e) & 0.92 \\
\hline
\end{tabular}



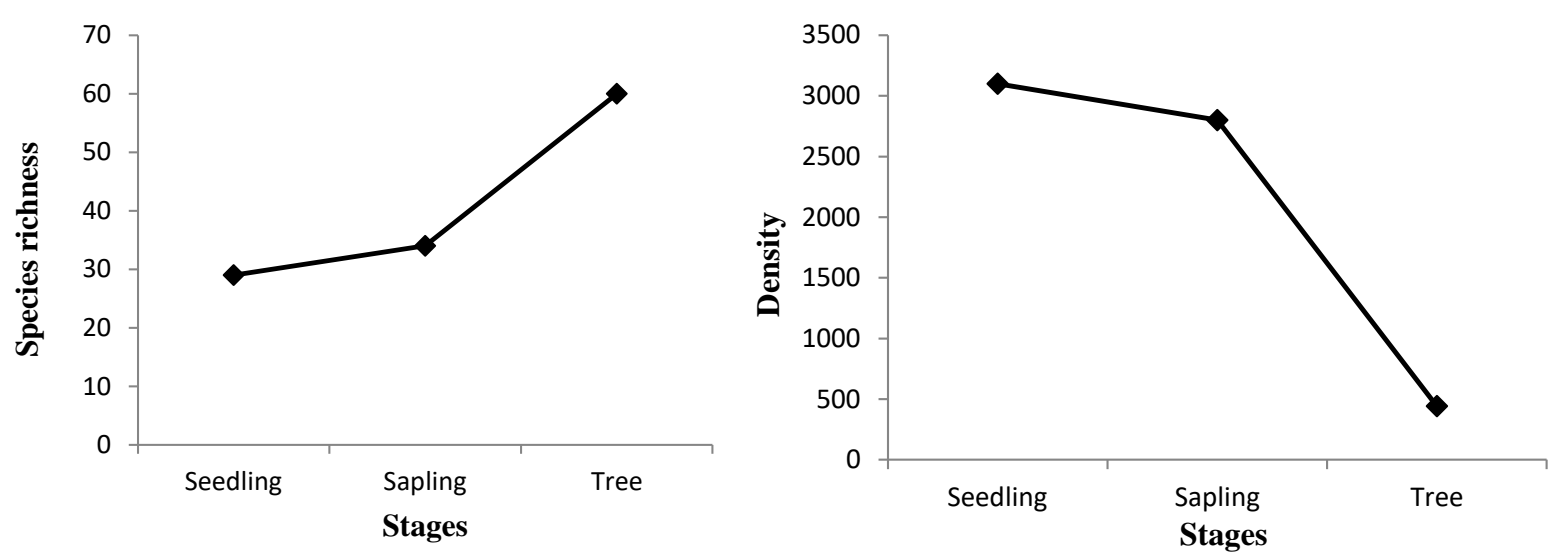

Figure 2. Species richness and density of seedling, sapling and tree species in Fakim Wildlife Sanctuary, Nagaland, Northeast India

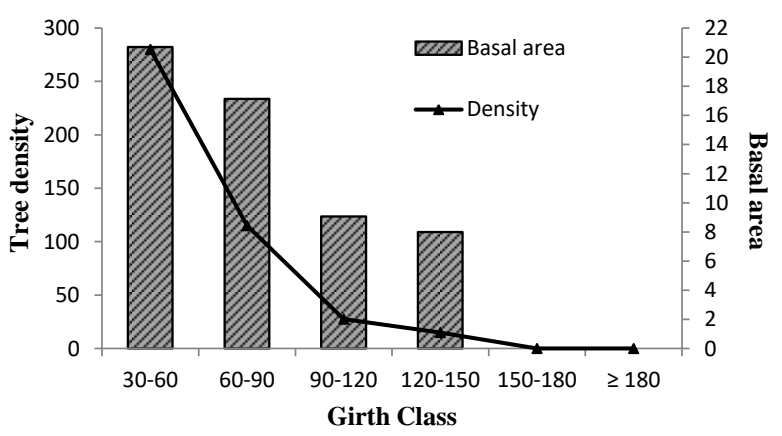

Figure 3. Tree density (individuals $\left.\mathrm{ha}^{-1}\right)$ and basal area $\left(\mathrm{m}^{2} \mathrm{ha}^{-1}\right)$ in different girth classes

However, among the trees, Aglaia perviridis, Beilschimedia roxburghiana, Brassaiopsis hainla, Cinnamomum zieylanicum, Exbucklandia populnea, Lithocarpus elegans, Magnolia insignis, Rhododendron arboretum contributed about one-fifth of the total tree density. Vegetation analysis of natural forest in North Sulawesi, Indonesia by Siregar et al. (2019) and Kedarnath Wildlife Sanctuary, Western Himalaya, India by Malik and Bhatt (2016) reported almost similar results. The overall population structure of tree vegetation in Fakim Wildlife Sanctuary showed a reverse J-shaped curve which signifies that the forest harbors a hale and hearty growth of population with no anomaly of species mortality rate.

The highest tree density (280 individuals $\mathrm{ha}^{-1}$ ) was recorded in $30-60 \mathrm{~cm}$ girth class showing that the two-third individuals were young. Corresponding values of tree density were: 115,28 , and 15 individuals $\mathrm{ha}^{-1}$ for girth class $60-90,90-120$, and $120-150 \mathrm{~cm}$, respectively. The maximum basal area $\left(21 \mathrm{~m}^{2} \mathrm{ha}^{-1}\right)$ was recorded in $30-60 \mathrm{~cm}$ girth class followed by $\left(17 \mathrm{~m}^{2} \mathrm{ha}^{-1}\right)$ in $60-90 \mathrm{~cm}$ girth class, $\left(9 \mathrm{~m}^{2} \mathrm{ha}^{-1}\right)$ 90-120 cm girth class and the lowest $\left(8 \mathrm{~m}^{2} \mathrm{~h}^{-1}\right)$ $120-150 \mathrm{~cm}$ girth class (Figure 3). Similar patterns were reported in temperate forest of Western Himalaya India (Tripathi et al 1987).

The study found that the density, species richness, and basal area of tree stand in Fakim Wildlife Sanctuary was the highest at the girth class of $30-60 \mathrm{~cm}$ and it consistently decreased as the girth size increased (Figure 3). This reflects that the area was facing anthropogenic pressure before the establishment of wildlife sanctuary in 1986. After the creation of wildlife sanctuary, the vegetation of the area regenerates well which is showed by the inverse Jshaped population density curves, indicating the growth of individuals at a lower girth class into a higher girth. A study conducted in Hollongapar Gibbon Wildlife Sanctuary, Assam showed a similar result where the overall density of tree in different girth class yielded a reverse Jshaped curve, indicating a good normal distribution of trees in various girth classes (Sarkar and Devi 2014).

\section{Regeneration status}

The regeneration potential of trees in a forest ecosystem reflects the future of the forest to provide goods and services to the society on sustained basis (Ali et al. 2019; Ballabha et al. 2013). Successful regeneration potential of a tree species depends on the ability of the species to produce large number of seeds and its ability to grow (Bogale et al. 2017; Jayakumar and Nair 2013). From the present study, $41 \%$ of tree species showed good regeneration status, $31 \%$ showed fair regeneration status, $8 \%$ showed poor regeneration status and 20\% showed no regeneration (Figure 4). Tree species exhibiting good regeneration potential included Acer pectinatum, Acer thomsonii, Berberis aristata, Caryota urens, Elaeocarpus floribundus, Litsea monopetala, Magnolia insignis, Prunus nepalensis, Sterculia coccinea, etc. Species showing fair regeneration status included Acer laevigatum, Acer oblongum, Albizia odoratissima, Betula alnoides, Cephalotaxus griffithii, Illicium griffithii, Magnolia tetracoccus, Prunus cerasoides, Rhododendron arboretum, Schima khasiana, Shorea assamica, Taxus baccata, etc. Species showing poor regeneration were Aglaia perviridis, Docynia indica, Litsea polyantha, Pyrus communis, and Quercus lamellosa. Species such as Cinnamomum zeylanicum, Ficus hirta, Ficus lamponga, Ilex excelsa, Lithocarpus xylocarpus, Rhamnus nepalensis, Turpinia spp. etc showed no regeneration (Table 2). 
Table 2. Tree species density (individual ha $\left.\mathrm{h}^{-1}\right)$, basal area $\left(\mathrm{m}^{2} \mathrm{ha}^{-1}\right)$, important value index (IVI) and regeneration status of Fakim Wildlife Sanctuary, Nagaland, Northeast India

\begin{tabular}{|c|c|c|c|c|c|}
\hline Species & Family & Density & Basal area & IVI & $\begin{array}{c}\text { Regeneration } \\
\text { status }\end{array}$ \\
\hline Acer laevigatum Wall. & Sapindaceae & 7.5 & 0.601131 & 3.903751 & $\mathrm{~F}$ \\
\hline Acer oblongum Wall. ex DC. & Sapindaceae & 16 & 0.883534 & 7.078191 & $\mathrm{~F}$ \\
\hline Acer pectinatum Wall. ex G. Nicholson & Sapindaceae & 7.5 & 0.534889 & 3.752177 & G \\
\hline Acer thomsonii Miq. & Sapindaceae & 7.5 & 0.981771 & 6.441394 & $\mathrm{G}$ \\
\hline Aglaia perviridis Hiern. & Meliaceae & 10 & 1.189646 & 6.648688 & $\mathrm{P}$ \\
\hline Albizia odoratissima (L.f.) Benth. & Fabaceae & 10 & 1.249350 & 6.785302 & $\mathrm{~F}$ \\
\hline Bauhinia divergens Baker & Fabaceae & 2.5 & 0.204657 & 1.866599 & $\mathrm{G}$ \\
\hline Beilschmiedia roxburghiana Nees & Lauraceae & 5 & 1.020596 & 4.298593 & $\mathrm{~F}$ \\
\hline Betula alnoides Buch.-Ham. ex. D. Don & Betulaceae & 15 & 1.270084 & 17.12936 & $\mathrm{~F}$ \\
\hline Berberis aristata DC. & Berberidaceae & 5 & 0.332526 & 2.72416 & $\mathrm{G}$ \\
\hline Brassaiopsis hainla (Buch.-Ham.) Seem. & Araliaceae & 10 & 0.829999 & 5.825749 & $\mathrm{G}$ \\
\hline Camellia oleifera Abel. & Theaceae & 10 & 1.500154 & 8.192525 & $\mathrm{G}$ \\
\hline Caryota urens $\mathrm{L}$. & Arecaceae & 7.5 & 0.648792 & 4.846141 & $\mathrm{G}$ \\
\hline Cephalotaxus griffithii Hook.f. & Cephalotaxaceae & 5 & 0.235902 & 2.503065 & $\mathrm{~F}$ \\
\hline Cinnamomum zeylanicum Blume & Lauraceae & 17.5 & 1.346128 & 9.534999 & $\mathrm{G}$ \\
\hline Cinnamomum spp. Schaeff & Lauraceae & 12.5 & 1.531408 & 8.829011 & NR \\
\hline Docynia indica (Wall.) Decne. & Rosaceae & 12.5 & 1.612068 & 8.180243 & $\mathrm{P}$ \\
\hline Elaeocarpus floribundus Blume & Elaeocarpaceae & 5 & 0.320467 & 2.696565 & G \\
\hline Elaeocarpus lanceifolius Roxb. & Elaeocarpaceae & 12.5 & 0.774638 & 7.097377 & G \\
\hline Elaeocarpus tectorius (Lour.) Poir. & Elaeocarpaceae & 10 & 1.263883 & 7.651891 & $\mathrm{G}$ \\
\hline Eurya acuminata DC. & Pentaphylacaceae & 2.5 & 0.133186 & 1.703059 & $\mathrm{G}$ \\
\hline Exbucklandia populnea (R.Br. ex Griff.) R.W.Br. & Hamamelidaceae & 12.5 & 1.795894 & 8.600871 & $\mathrm{G}$ \\
\hline Ficus hirta Vahl & Moraceae & 2.5 & 0.140446 & 1.719672 & NR \\
\hline Ficus lamponga Miq. & Moraceae & 2.5 & 0.143134 & 1.725822 & NR \\
\hline Ficus racemosa $\mathrm{L}$. & Moraceae & 5 & 0.280657 & 3.438806 & G \\
\hline Garcinia anomala Planch. \& Triana & Clusiaceae & 5 & 0.274994 & 2.592516 & G \\
\hline Garcinia cowa Roxb. Ex Choisy & Clusiaceae & 2.5 & 0.126118 & 1.686887 & $\mathrm{~F}$ \\
\hline Hydnocarpus kurzii (King) Warb. & Achariaceae & 2.5 & 0.193510 & 1.841093 & G \\
\hline Ilex excels (Wall.) Voigt & Aquifoliaceae & 2.5 & 0.093670 & 1.612639 & NR \\
\hline Illicium griffithii Hook.f. \& Thomson & Schisandraceae & 5 & 0.254581 & 2.545807 & $\mathrm{~F}$ \\
\hline Lithocarpus elegans (Blume) Hatus. ex Soepadmo & Fagaceae & 10 & 1.111982 & 8.137647 & G \\
\hline Lithocarpus pachyphyllus (Kurz) Rehder & Fagaceae & 17.5 & 2.641110 & 12.49816 & $\mathrm{G}$ \\
\hline Lithocarpus xylocarpus (Kurz) Markgr. & Fagaceae & 10 & 1.308088 & 8.586374 & NR \\
\hline Litsea monopetala (Roxb.) Pers. & Lauraceae & 5 & 0.510902 & 3.132318 & $\mathrm{G}$ \\
\hline Litsea polyantha Juss. & Lauraceae & 2.5 & 0.110771 & 1.651771 & $\mathrm{P}$ \\
\hline Macropanax dispermus (Blume) Kuntze & Araliaceae & 5 & 0.605295 & 3.348307 & $\mathrm{~F}$ \\
\hline Magnolia champaca (L.) Baill. ex Pierre & Magnoliaceae & 2.5 & 0.188054 & 1.828609 & G \\
\hline Magnolia campbelli Hook.f. \& Thomson & Magnoliaceae & 5 & 0.398905 & 2.876048 & $\mathrm{G}$ \\
\hline Magnolia insignis Hook.f. \& Thomson & Magnoliaceae & 16 & 1.218196 & 9.510627 & $\mathrm{~F}$ \\
\hline Mallotus tetracoccus (Roxb.) Kurz & Euphorbiaceae & 2.5 & 0.202242 & 1.861073 & $\mathrm{~F}$ \\
\hline Michelia oblonga (Wall.) Hook.f. \& Thomson & Magnoliaceae & 15 & 2.032598 & 11.37413 & $\mathrm{~F}$ \\
\hline Phoebe lanceolata (Nees) Nees & Lauraceae & 7.5 & 0.796020 & 6.01636 & NR \\
\hline Prunus cerasoides Buch.-Ham. ex. D. Don & Rosaceae & 7.5 & 0.898029 & 6.249775 & $\mathrm{~F}$ \\
\hline Prunus nepalensis Hook.f. & Rosaceae & 2.5 & 0.221962 & 1.906196 & $\mathrm{G}$ \\
\hline Pyrus pashia Buch.-Ham. ex. D. Don & Rosaceae & 10 & 0.494212 & 5.057404 & NR \\
\hline Pyrus communis $\mathrm{L}$. & Rosaceae & 5 & 0.256957 & 2.551243 & $\mathrm{P}$ \\
\hline Quercus lamellose $\mathrm{Sm}$. & Fagaceae & 12.5 & 1.932982 & 10.58122 & $\mathrm{P}$ \\
\hline Rhamnus nepalensis (wall.) Lawson & Rhamnaceae & 5 & 0.348371 & 2.760416 & NR \\
\hline Rhododendron arboretum $\mathrm{Sm}$. & Ericaceae & 12.5 & 1.240419 & 8.163172 & $\mathrm{~F}$ \\
\hline Rhododendron spp. L. & Ericaceae & 2.5 & 0.227886 & 1.919752 & NR \\
\hline Schima khasiana Dyer & Theaceae & 2.5 & 0.164829 & 1.775465 & $\mathrm{~F}$ \\
\hline Schima wallichii Choisy & Theaceae & 7.5 & 0.744736 & 4.232347 & $\mathrm{~F}$ \\
\hline Shorea assamica Dyer & Dipterocarpaceae & 2.5 & 0.201440 & 1.859239 & $\mathrm{~F}$ \\
\hline Sterculia coccinea Roxb. & Malvaceae & 2.5 & 0.197455 & 1.85012 & G \\
\hline Taxus baccata $\mathrm{L}$. & Taxaceae & 12.5 & 1.096753 & 7.001104 & $\mathrm{~F}$ \\
\hline Toona ciliata M.Roem. & Meliaceae & 5 & 0.717998 & 4.439525 & $\mathrm{~F}$ \\
\hline Toona sureni (Blume) Merr. & Meliaceae & 2.5 & 0.201440 & 1.859239 & G \\
\hline Turpinia spp. Vent. & Staphyleaceae & 5 & 0.386380 & 2.847387 & NR \\
\hline Ziziphus incurva Roxb. & Rhamnaceae & 2.5 & 0.152045 & 1.746214 & NR \\
\hline
\end{tabular}

$* \mathrm{G}=$ Good regeneration, $* \mathrm{~F}=$ Fair regeneration, $* \mathrm{P}=$ Poor regeneration, $* \mathrm{NR}=$ No regeneration 


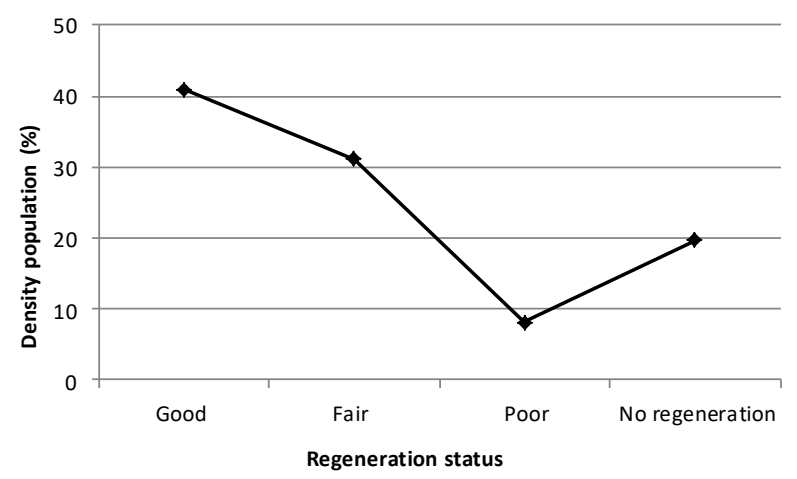

Figure 4. Regeneration status of tree species in Fakim Wildlife Sanctuary, Nagaland, Northeast India

The overall regeneration status of the Fakim wildlife sanctuary showed reversed J-shaped curve with a higher percentage of species exhibiting good regeneration status. This condition is referred to as good health of forest where majority of the species showed good regeneration status. Similar results were reported on regeneration status of the sub-tropical forest of Alaknanda valley in Garwhal Himalaya, India (Ballabha et al. 2013). The tree species from the sanctuary showing poor and no regeneration may be accorded due to the large canopy cover that reduces the sunlight which may inhibit the growth of the species because of the limitation of sunlight (Fiorucci and Fankhauser 2017).

The dominance-diversity curve (i.e. the percentage of IVI on log scale plotted against species rank) of trees, sapling and seedling in Fakim Wildlife Sanctuary showed a reasonable amount of diversity (Figure 5). The dominant tree species with the highest IVI were Beilschimedia roxburghiana, Lithocarpus elegans, Michelia oblonga, Quercus lamellosa, Magnolia campbelli, Exbucklandia populnea, Lithocarpus xylocarpus, Acer oblongum, Albizia odoratissima, Prunus cerasoides and Phoebe lanceolata, whereas species such as Brassaiopsis hainla, Pyrus pashia, Mallotus tetracoccus, Ilex excelsa, Eurya acuminata, Ficus hirta, Bauhinia divergens had the lowest IVI. The sharp decline on the curve is found in species with lower girth class which is likely due to the impact of anthropogenic factors.

The dominance-diversity curve for saplings and seedlings showed a gentle slope which is a normal characteristic of vegetation having a positive regeneration potential of a species. The dominant sapling and seedling of with the highest IVI were Acer pectinatum, Acer thomsonii, Berberis aristata, Elaeocarpus floribundus, Litsea monopetala, Magnolia insignis, Prunus nepalensis, Michelia oblonga and Lithocarpus elegans. The gentle decline in the dominance-diversity curve of saplings and seedlings indicates the disturbance due to grazing by the wild herbivores such as Mithuns (Bos frontalis) which were found abundant in the sanctuary. The dominance-diversity curve of all the tree, sapling and seedling follows S-shaped

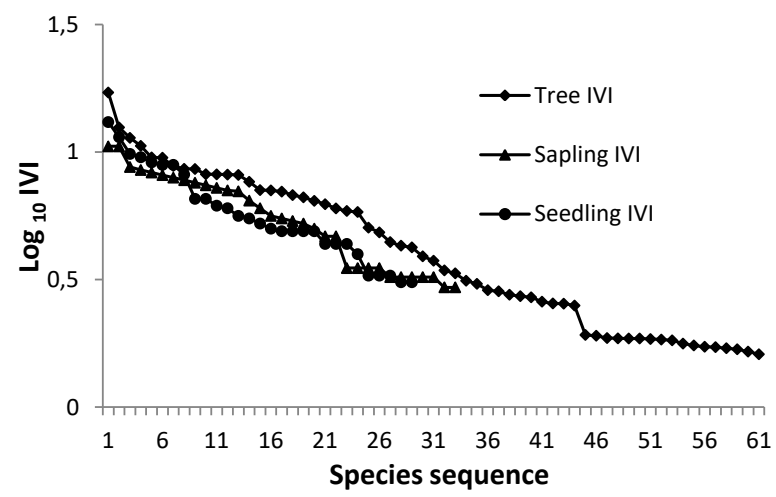

Figure 5. Dominance-diversity curve of trees, saplings, and seedlings in Fakim Wildlife Sanctuary, Nagaland, Northeast India

$\log$ series model which indicates that the sanctuary is a species-rich region.

In conclusion, the forest of Fakim Wildlife Sanctuary is rich in tree diversity with higher density in seedlings, sapling and young trees, indicating a good regeneration potential that can be sustained for a longer time with proper management plans to provide good and services to the society. Attention is required to facilitate the regeneration of species which are not performing well due to environmental constrains, particularly light as a result of shade from canopy trees. Decreased numbers of individuals in the upper girth class draw attention of the forest managers towards any logging activities in the border area of the sanctuary by the local people residing in the surrounding villages. Therefore, an efficient management plan is needed to conserve the vegetation and health of the Fakim Wildlife Sanctuary in order to provide sustainable use of the forest resources.

\section{ACKNOWLEDGEMENTS}

We thank authorities of Nagaland Forest Department for granting permission to study the vegetation of Fakim Wildlife Sanctuary and the support rendered by local residents of Fakim village for their assistance during the course of the study. The Department of Forestry, Mizoram University is thankfully acknowledged for providing various support during the course of the study.

\section{REFERENCES}

Ahmadi F, Sadeghi AR, Eskandarinezhad AR. 2016. Ecological quality improvement of urban landscapes with emphasis on sustainable development principles case study: River of Darabad Valley, Tehran, Iran. Eur J Sustain Dev 5 (3): 91-102. DOI: 10.14207/ejsd.2016.v $5 \mathrm{n} 3 \mathrm{p} 91$

Airi S, Rawal RS. 2017. Patterns of vegetation composition across levels of canopy disturbance in temperate forests of west Himalaya, India. Biodivers Res Conserv 45: 27-33. DOI: 10.1515/biorc-2017-0004

Ali A, Dai D, Akhtar K, Teng M, Yan Z, Cardona N, Mullerova J, Zhou Z. 2019. Response of understory vegetation, tree regeneration, and soilquality to manipulated stand density in a Pinus massoniana 
plantation. Global Ecol Conserv 20: e00775. DOI 10.1016/j.gecco.2019.e00775

Arisdason W, Lakshminarasimhan P. 2017. Status of plant diversity in India: An overview. ENVIS Centre on floral diversity www.bsienvis.nic.in/Database/Status_of_Plant_Diversity_in_India_1 7566.aspx

Arrijani, Rizki M. 2020. Vegetation analysis and population of tarsier (Tarsius spectrumgurskyae) at Batuputih Nature Tourism Park, North Sulawesi, Indonesia. Biodiversitas 20 (2): 530-537. DOI: $10.13057 /$ biodiv/d210214

Ballabha R, Tiwari JK, Tiwari P. 2013. Regeneration of tree species in the sub-tropical forest of Alaknanda Valley, Garhwal Himalaya, India. For Sci Pract 15: 89-97. DOI: 10.1007/s11632-013-0205-y

Bhutia Y, Gudasalamani R, Ganesan R, Saha S. 2019. Assessing forest structure and composition along the altitudinal gradient in the state of Sikkim, Eastern Himalayas, India. Forests 10: 633. DOI: 10.3390/f10080633

Bogale T, Datiko D, Belachew S. 2017. Structure and natural regeneration status of woody plants of berbere afromontane moist forest, bale zone, South East Ethiopia; implication to biodiversity conservation. J For 7 , 352-371. DOI: 10.4236/ojf.2017.73021

Borogayary B, Das AK, Nath AJ. 2017. Tree species composition and population structure of a secondary tropical evergreen forest in Cachar district, Assam. J Environ Biol 39 (1): 67-71.

Champion HG, Seth SK. 1968. A Revised Survey of Forest Types of India, Govt. of India Press, New Delhi,

Chatterjee S, Saikia A, Dutta P, Ghosh D, Pangging G, Goswami AK. 2006. Biodiversity Significance of North East India. WWF India.

Chaturvedi RK, Raghubanshi AS, Tomlinson KW, Singh JS. 2017. Impacts of human disturbance in tropical dry forests increase with soil moisture stress. J Veg Sci 28: 997-1007. DOI: 10.1111/jvs.12547

Deb JC, Roy A, Wahedunnabi MD. 2015. Structure and composition of understory treelets and overstory trees in a protected area of $\begin{array}{lllllll}\text { Bangladesh. } & \text { For Sci Technol } 11 & \text { (2): } & 76-85 . & \text { DOI }\end{array}$ 10.1080/21580103.2014.966861

Deb P, Sundriyal RC. 2011. Vegetation dynamics of an old-growth lowland tropical rainforest in North-east India: species composition and stand heterogeneity. Int J Biodivers Conserv 3 (9): 405-430. DOI 10.14419/ijbas.v3i4.3323

Dutta G, Devi A. 2013. Plant diversity, population structure and regeneration status in disturbed tropical forests in Assam, northeast India. J For Res 24:715-720. DOI: 10.1007/s11676-013-0409-y

Erenso F, Maryo M, Wendawek A. 2014. Floristic composition, diversityand on structure of woody plant communities in boda dry evergreen montane forest, West Showa, Ethiopia. Biodivers Conserv 6 (5): 382-391. DOI: 10.5897/IJBC2014.0703

Fiorucci AS, Fankhauser C. 2017. Plant strategies for enhancing access to sunlight. Curr Biol 27 (17): 931-940. DOI: 10.1016/j.cub.2017.05.085

Gairola S, Rawat RS, Todaria NP. 2008. Forest vegetation patterns along an altitudinal gradient in sub-alpine zone of west Himalaya, India. Afr J Plant Sci 2 (6): 042-048.

Gandhi DS, Sundarapandian S. 2020. Plant Diversity and Distribution Pattern in Tropical Dry Deciduous Forest of Eastern Ghats, India. In: Roy N, Roychoudhury S, Nautiyal S, Agarwal S, Baksi S (eds) Socio-economic and Eco-biological Dimensions in Resource use and Conservation. Environmental Science and Engineering. Springer, Cham. DOI: 10.1007/978-3-030-32463-6_8

Gazol A, Ibanez. 2010. Variation of plant diversity in a temperate unmanaged forest in northern Spain: behind the environmental and spatial explanation. Plant Ecol 207: 1-11. DOI 10.1007/s11258-0099649-5.

Jayakumar R, Nair KK. 2013. Species diversity and tree regeneration patterns in tropical forests of the Western Ghats, India. ISRN Ecology Volume 2013, Article ID 890862. DOI: 10.1155/2013/890862

Khumbongmayum AD, Khan ML, Tripathi RS. 2006. Biodiversity conservation in sacred groves of Manipur, northeast India: population structure and regeneration status of woody species. Biodiversity and Conservation 15: 2439-2456.

Lynser MB, Tiwari BK. 2015. Tree diversity, population structure and utilization in traditionally managed sub-tropical wet evergreen fores of Meghalaya, Northeast India. Int Res J Environ Sci 4 (12): 1-5.

Malik AZ, Bhatt AB. 2016. Regeneration status of tree species and survival of their seedlings in Kedarnath Wildlife Sanctuary and its adjoining areas in Western Himalaya, India. Trop Ecol 57 (4): 677690.
Mane AM, Prabakaran N, Manchi SS. 2019. Floral diversity, composition, and recruitment on the karstland of Baratang Island, India. Ecol Complexity 37 (2019): 47-54. DOI: 10.1016/j.ecocom.2018.11.002

Margalef DR. 1958. Information theory in ecology. Gen Syst 3: 36-71.

Maua JO, Tsingalia HM, Cheboiwo J, Odee D. 2020. Population structure and regeneration status of woody species in a remnant tropical forest: A case study of South Nandi forest, Kenya. Global Ecol Conserv 21 (2020), e00820. DOI: 10.1016/j.gecco.2019.e00820

Mestre L, Toro-Manríquez M, Soler R, Huertas-Herrera A, MartínezPasturand G, Lencinas MV. 2017. The influence of canopy-layer compositionon understory plant diversity in southerntemperate forests. For Ecosyst 4: 6. DOI: 10.1186/s40663-017-0093-z

Monson RK. 2014. Ecology of Temperate Forests. In: Monson R. (ed) Ecology and the Environment. The Plant Sciences, vol 8. Springer, New York, NY. DOI: 10.1007/978-1-4614-7501-9_5

Naidu MT, Kumar OA. 2016. Tree diversity, stand structure and community compospition of tropical forest in Eastern Ghats of Andhra Pradesh, India. J Asia-Pac Biodivers 9: 328-334. DOI: 10.1016/j.japb.2016.03.019

Ndah NR, Andrew EE, Bechem E. 2013. Species composition, diversity and distribution in a disturbed Takamanda rainforest, Southwest $\begin{array}{llllll}\text { Cameroon. Afr J Plant Scie 7: 577-585. DOI: } & \end{array}$ 10.5897/AJPS2013.1107

Palit D, Pal S, Chanda S. 2012. Diversity and richness of plants in Darjeeling Himalaya with an eye on Gaddikhana forest beat, Senchal east zone forest range, Darjeeling. Indian J For 35 (1): 39-44.

Pielou EC. 1966. The measurement of diversity in different types of biological collections. J Theor Biol 13: 131-144.

Pokhriyal P, Uniyal P, Chauhan DS, Todaria NP. 2010. Regeneration status of tree species in forest of Phakot and Pathri Rao watersheds in Garhwal Himalaya. Curr Scie 98 (2): 171-175.

Rahman MH, Khan AS, Roy B, Fardusi MJ. 2011 Assessment of natural regeneration status and diversity of tree species in the biodiversity conservation areas of Northeastern Bangladesh. J For Res 22 (4): 551559. DOI: $10.1007 / \mathrm{s} 11676-011-0198-0$

Rahman MR, Rahman MM, Chowdhury MA. 2019. Assessment of natural regeneration status: the case of Durgapur hill forest, Netrokona, Bangladesh, Geology, Ecology, and Landscapes. J Geol Ecol Landsc. DOI: $10.1080 / 24749508.2019 .1600911$

Raturi GP. 2012. Forest community structure along an altitudinal gradient of District Rudraprayag of Garhwal Himalaya, India. Ecologia 2 (3): 76-84. DOI: $10.3923 /$ ecologia.2012.76.84

Rawal RS, Rawal R, Rawat B, Nehi VS, Pathak R. 2018. Plant species diversity and rarity patterns along the altitude range covering treeline ecotone in Uttarakhand: conservation implications. Trop Ecol 59 (2): 225-239.

Rongsensashi, Mozhui R, Changkija S, Limasenla 2013. Medicinal plant diversity of Fakim Wildlife Sanctuary, Nagaland India. East Himalayan Soc Spermatophyte Taxon 7 (1): 110-126.

Roy A, Das SK, Tripathi AK, Singh NU, Barman HK. 2015. Biodiversity in Northeast India and its conservation. Progressive Agric 15 (2): 182-189. DOI: 10.5958/0976-4615.2015.00005.8

Roy A, Tripathi SK and Basu SK. 2004. Formulating diversity vector for ecosystem comparison. Ecol Modeling 179 (4): 499-513.

Saha S, Rajwar GS, Kumar M. 2016. Forest structure, diversity and regeneration potential along altitudinal gradient in Dhanaulti of Garhwal Himalaya. For Syst 25 (2): 1-15. DOI: 10.5424/fs/201625207432

Sahu SC, Pani AK, Mohanta MR, Kumar J. 2019. Tree species diversity, distribution and soil nutrient status along altitudinal gradients in Saptasajya hill range, Eastern Ghats, India. Taiwania 64 (1): 28-38. DOI: $10.6165 /$ tai.2019.64.28

Saikia P, Deka J, Bharali S, Kumar A, Tripathi OP, Singha LP, Dayanandan S, Khan ML. 2017. Plant diversity patterns and conservation status of eastern Himalayan forests in Arunachal Pradesh, Northeast India. For Ecosyst (2017) 4: 28 DOI: 10.1186/s40663-017-0117-8

Saikia P, Khan ML. 2013. Population structure and regeneration status of Aquilaria malaccensis Lam. in homegardens of Upper Assam, northeast India. Trop Ecol 54 (1): 1-13.

Saikia P, Khan ML. 2017. Floristic diversity of North East India and its Conservation Initiatives. Plant Diversity in the Himalaya Hotspot Region. M/s. Bishen Singh Mahendra Pal Singh, Dehradun, India.

Sarkar M, Devi A. 2014. Assessment of diversity, population structure and regeneration status of tree species in Hollongapar Gibbon 
Wildlife Sanctuary, Assam, Northeast India. Trop Plant Res 1 (2): 26 36.

Saroinsong FB. 2020. Supporting plant diversity and conservation through landscape planning: A case study in an agro-tourism landscape in Tampusu, North Sulawesi, Indonesia. Biodiversitas 21 (4): 15181526. DOI: $10.13057 /$ biodiv/d210432

Sathish BN, Vis wanath S, Kushalappa CG, Jagadish MR, Ganeshaiah KN. 2013. Comparative assessment of floristic structure, diversity and regeneration status of tropical rain forests of Western Ghats of Karnataka, India. J Appl Nat Sci 5 (1):157-164

Senbeta F, Schmitt C, Woldermariam T, Boehmer H,Denich M. 2014 Plant diversity, vegetation structure and relationship between plant communities and environmental variables in Afromontane forests in Ethiopia. Ethiopian J Sci 37 (2): 113-130

Shankar U. 2001. A case of high tree diversity in a sal (Shorea robusta)dominated lowland forest of Eastern Himalaya: Floristic composition, regeneration and conservation. Curr Sci 81 (7): 776-786.

Shannon CE and Weaver W. 1963. The Mathematical Theory of Communication. University of Illinois Press, Urbana, USA.

Sharma MC, Mishra KA, Tiwari PO, Krishan R, Rana SY. 2018 Regeneration Patterns of Tree Species Along anElevational Gradient in the Garhwal Himalaya. Mount Rese Dev 38 (3): 211-219. DOI 10.1659/MRD-JOURNAL-D-15-00076.1

Sharma N, Kant S. 2014. Vegetation structure, floristic composition and species diversity of woody plant communities in sub-tropical Kand Siwaliks of Jammu and Kashmir, India. Int J Basic Appl Sci 3 (4): 382-391.

Sharma P, Rana JC, Devi U, Randhawa SS, Kumar R. 2014. Floristic diversity and distribution pattern of plant communities along altitudinal gradient in Sangla Valley, Northwest Himalaya. Sci World J. ID 264878. DOI: 10.1155/2014/264878

Simpson EH. 1949. Measurement of diversity. Nature 163: 168.

Singh S, Malik ZA, Sharma CM. 2016. Tree species richness, diversity, and regeneration status in different oak (Quercus spp.) dominated forests of Garhwal Himalaya, India. J Asia-Pac Biodivers 9 (2016) 293-300. DOI: $10.1016 /$ j.japb.2016.06.002

Singh SB, Mishra BP, Tripathi SK. 2015. Recovery of plant diversity and soil nutrients during stand development in subtropical forests of Mizoram, Northeast India. Biodiversitas 16 (2): 205-212. DOI 10.13057/biodiv/d160216
Siregar M, Helmanto H, Rakhmawati SU. 2019. Vegetation analysis of tree communities at some forest patches in North Sulawesi, Indonesia. Biodiversitas 20 (3): 643-655. DOI: 10.13057/biodiv/d200305

Sobuj NA, Rahman M. 2011. Assessment of plant diversity in Khadimnagar National Park of Bangladesh. Int J Environ Sci 2 (1):79-91.

Somasundaram S, Lalitha V. 2010. Plant diversity and phenological pattern in the montane wet temperate forests of the southern Western Ghats, India. For Stud 12: 116-125. DOI: 10.1007/s11632-010-03020

Subashree K, Dar JA, Karuppusamy S, Sundarapandian S. 2020. Plant diversity, structure and regeneration potential in tropical forests of Western Ghats, India. Acta Ecol Sin (2020). DOI: 10.1016/j.chnaes.2020.02.004

Trimanto, Hapsari L. 2016. Botanical survey in thirteen montane forests of Bawean Island Nature Reserve, East Java Indonesia: Flora diversity, conservation status, and bioprospecting. Biodiversitas 17 (2): 832-846. DOI: 10.13057/biodiv/d170261

Tripathi SK, Verma KR, Upadhyay VP. 1987. Analysis of forest vegetation at Kasar Devi Hill of north-west Almora Division in Kumaun Himalaya. Proc Indian Acad Sci (Plant Sci) 97: 265-276.

Tynsong H, Tiwari BK. 2010. Diversity of plant species in arecanut agroforest of south Meghalaya, north-east India. J For Res 21: 281286. DOI: $10.1007 / \mathrm{s} 11676-010-0072-5$

Uniyal P, Pokhriyal P, Dasgupta S, Bhatt B, Todaria NP. 2010. Plant diversity in two forest types along the disturbance gradient in Dewalgarh Watershed, Garhwal Himalaya. Curr Sci 98 (7): 938-943.

Upadhaya K, Choudhury H, Odyuo N. 2012. Floristic Diversity of Northeast India and its Conservation. International Environmental Economics-Biodiversity and Ecology. Edition: $1^{\text {st }}$ Chapter: Floristic Diversity of Northeast India and its Conservation. Discovery Publishing House Pvt. Ltd., New Delhi

Yam G, Tripathi OM. 2016. Tree diversity and community characteristics in Talle Wildlife Sanctuary, Arunachal Pradesh, Eastern Himalaya, India. J Asia-Pac Biodivers 9 (2016): 160-165. DOI: 10.1016/j.japb.2016.03.002

Zhang Y, Chen HY, Taylor AR. 2017. Positive species diversity and above-ground biomass relationships are ubiquitous across forest strata despite interference from overstorey trees. Funct Ecol 31: 419-426. DOI: $10.1111 / 1365-2435.12699$ 